【論文】

UDC : 624. $04: 624.074$
日本建築学会構造系論文報告集 第 412 号・1990 年 6 月 Journal of Struct. Constr. Engng, AIJ, No. 412, June, 1990

\title{
構造物の安定性に関する知識整理と安定判断システム KNOWLEDGE-BASED EXPERT SYSTEM FOR STABILITY ANALYSIS OF PLANE TRUSS STRUCTURES
}

\author{
加藤史 郎*, 杉山武**, 山口源一郎***, 河 合 正 晃****, \\ Shiro KATO, Takeshi SUGIYAMA, Gen-ichirou YAMAGUTI and Masaaki KAWAI
}

This paper reports on an elementary approach to AI (Artificial Inteligence) in structual engineering from the following view points ;

(1) knowledge acquisition on stability of plane truss structures,

(2) a knowledge-based expert system to judge the structual stability.

Structural engineers can recognize, as a visual image, truss structures as a chain of members and connected nodes. Therefore, in this paper, the representation of structual information can be considered as a concept of network. The knowledge representation is based on production rules. Reasoning stable structures in this system is interpreted as searching a network judging from knowledge bases. In this system, unstable modes are also analyzed by numerical method, and can be displayed on CRT.

This system is implemented on a personal computer running under a MS-DOS operating system. The programing language for judgement is Prolog, which has a powerful pattern matching capability. The programing language for numerical analysis is Fortran.

Keywords : Expert System, Stability Analysis, Plane Truss Structures, Production Rules, Prolog, AI

\section{1.はじめに}

近年, 人工知能技術の研究が盛んに行われ，この人工 知能技術は様々な分野で利用されてきている。人工知能 忘用技術の一つとしてエキスパートシステムがある。エ キスパートシステムとは、コンピュータに蓄積された特 定分野の専門知識を用いて, 専門家に近い能力で問題解 決を行うシステムである。このようなエキスパートシス テムは診断, 計画, 生産管理などの様々な分野で構築さ れている(13),171,18)。最近では，建築土木の分野において もコンクリートのひび割れ診断システム ${ }^{17)}$ や最適土地利 用企画エキスパート・システム ${ }^{18)}$ な゙゙が構築されてい る。

構造工学における従来の研究は, 理論ならびにそれに 基づく実験，および数值実験であった。それらの研究か ら実証的でかつ数值を伴う確かな知識が豊富に蓄積され てきた。それらの知識は, 研究者, 技術者の思考過程に おいて有効に活かされ多くの実績を上げてきた。しかし ながら,これらの本質的かつ有益な知識は「紙」の上に 蓄えられ，その使用に当たっても知識の反復的な訓練が
必要であった。例えば, 構造の豊富な知識を持つ人間は, 平面トラス構造物の安定判断を行う場合, 従来の安定性 の判断法のような数式的なものを使わず，物理的現象と してとらえた定性的な知識によって直観的に安定・不安 定を判断している。つまり, 実験や数值解析の経験をと おして安定な構造形態または不安定な構造形態の経験的 知識を蓄積し，この経験的知識に基づいて安定な構造形 態または不安定な構造形態を見つけ出すことによって判 断していると言える。

このような経験的知識を整理し計算機上に蓄積したシ ステムを構築すれば, このシステムは, ある研究者や技 術者だけの知識だけでなく, 経験的知識の少ない学生な どの知識の一領域として共有できるようになる。また, このシステムにおいてよ゙のように知識を用いて判断して いるかという推論過程を表示することにより, 研究者や 技術者の思考過程を知ることができ, 自らの知識とする こともできる。

本研究は, 構造工学の分野においても知識ベースアプ ローチが効果的に適用できることを示すために，限られ

\footnotetext{
* 豊橋技術科学大学 教授・工博

***(株) 中部電力 副主查研究員

*** (株) 中部

**** 日本電信電話株式会社
}

Professor, Toyohashi University of Technology, Dr. Eng.

Senior Research Engineer, Chubu Electric Power Company Ltd. Chubu Engineering Company Ltd.

Nippon Telegraph and Telephone Corporation 
たテーマであるが必要かつ十分である知識のほかにある 経験的知識の代表として, 構造力学の基礎的問題である 平面トラスの安定判断問題をとらえ, (1) 構造物の安 定性に関する知識整理と, 安定な構造を見つけ出してい く一種の探索問題として（2）知識ベースに基づく判断 システムの試作を行った ${ }^{2), 11}$ 。

\section{2. 安定性に関する知識整理}

構造力学の教科書などで扱われている平面トラスの安 定判別式 (( 1$)$ 式 $)^{3)}$ は、トラス構造物が安定となるた めの最小限に必要な条件であり, また, この条件を满足 していても安定であるとは限らない。

$$
\begin{aligned}
& r: \text { 反力数 } \\
&(r+m)-2 j \geqq 0 \quad(1) \quad m: \text { 部材数 } \\
& j: \text { 節点数 }
\end{aligned}
$$

安定や不安定の判断は，このような判別式だけでは不 十分であり，判別式のほかに部材の配置やつながり，支 持の方法などの要因も含めた安定に関する知識が必要で ある。

また, トラスの知識を持つ人間は, むしろ（1）式の ような数式を使わず経験的に安定 ・不安定を判断するこ とができる。つまり, 経験をとおしてトラス構造の安定 な構造形態または不安定な構造形態の経験的知識を蓄積 し，この経験的知識に基づいてトラス構造全体について 一度に判断するのではなく, 部分的に安定な構造形態ま たは不安定な構造形態を見つけ出すことの繰り返しに よって構造全体の判断を行っていると考えられる。本研 究は,このように部分的に安定な構造形態を見つけるこ とを一種の探索問題としてとらえ, 探索問題に適切な言 語であるProlog 言語蛙)を用いて表現した。また，経験 的知識は, 数值的なものではなく言語的なものであるこ とから，言語関数的な理論構成によって推論することが できるプロダクションルール10),12) 14)を応用している。

図一1は，本研究における安定判断の基本的な概念を 表したものである。安定判断の推論は，すでに安定した 部分構造から導かれた安定節点に関する事実と知識ベー ス中の経験的知識とを利用して, 安定した部分構造を新 しく探し出し, 新しい安定節点を事実としてデータベー スに記憶していくことの繰り返しである。推論は安定し た部分構造が新しく探し出せないとき終了する。トラス の安定・不安定の判断は，推論を終了したときに，すべ ての節点について安定が導かれたならば構造全体を安定 と判断し，安定とされない節点が存在するならば不安定

注 1) Prologは，事物の性質や意味・事物間の関係なぼを 表現する述語理論の体系を基礎としている。Prolog は ユニフィケーション機能 (パターンマッチング機能), 推論機能 (三段論法) とバックトラック機能を有してお り，トラスの安定な構造形態を発見することなどに必要 となる探索問題に適しているため，Prologを採用した。
構造と判断する。

ここで，対象とする構造や判断に必要な経験的知識を あらかじめ記号化または言語化しなければならない。人 間は安定判断の対象とするトラス構造を視覚的に認識す ることができるため, 安定な構造形態に関する経験的知 識は節点と部材とのつながりの連鎖のような視覚的イ メージとして蓄積されていると考えられる。この節点と 部材とのつながりという考え方から，トラス構造の記号 化は，節点をノード，部材をアークとみなすネットワー クの概念を用いている。したがって，部材は，図一2(a) のように節点間のつながりを表すネットワーク情報とし ている。また，経験的知識は，安定な構造形態がどのよ うなネットワークで構成されているかによって表現する ことができる。よって, 安定判断の推論で行う部分構造 の導出は, 経験的知識に基づいたネットワークの探索に よって行える。

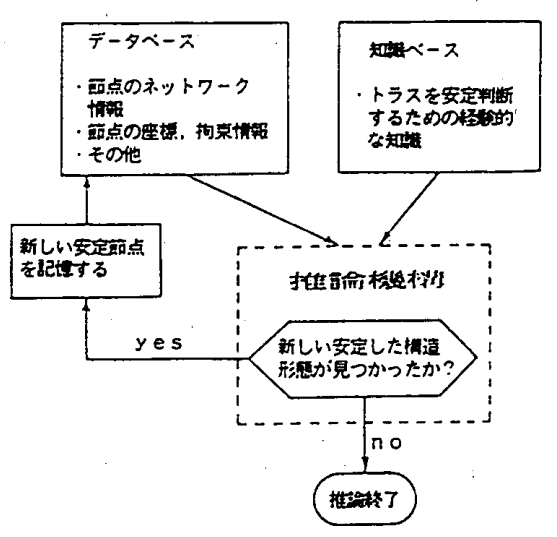

図一1 トラスの安定判断システムの基本構成と推論方針

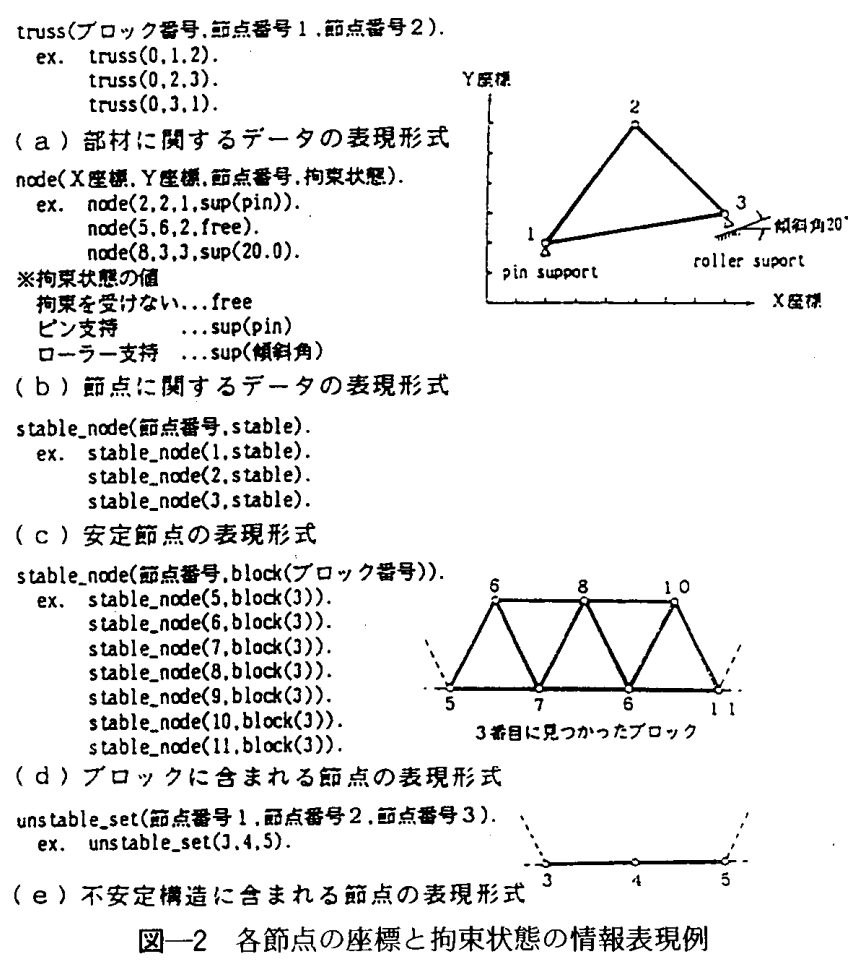

b )西点泪阅するデータの素現形式

stable_node(苜点番号. stable).

stable_node (1, stable) stable,node (2,stable).

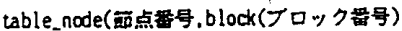

x. stable_node(5,blodk(J)) stable node $(6, b \operatorname{lock}(3))$. stable_node $(7$, block(3)) table_node $(8$, block $(3))$ table node $(9$, block $(3))$. table node (10, block (3)) stable_node(11.block(3))

(d)フロックに含ま机る原点の表現形式

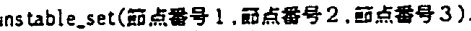
ex. unstable_set $(3,4,5)$

図一2 各節点の坐標之拘束状態の情報表現例 
安定判断には部材の配置や支持方法などが要因となる ため，各節点の座標と拘束状態の情報を図一 $2(\mathrm{~b})$ のよ うに表現する。

\section{2-1 平面卜ラスの安定節点と安定構造}

本研究で用いる平面トラスの安定判断は，主に初等的 な構造力学 ${ }^{3)}$ の経験的知識に基づいている。安定節点は,

・ピン支持された節点

・節点に荷重をどの方向から作用させたときでも, 節点 が微小変位の範囲内で変位することにより部材軸力と 荷重とのつり合いがとれるような節点

と定義する(図一 3 )。

次に，図一4(a)，(b) のような不安定構造を考える。 (a), (b) ともに微小変位の範囲内において䞒体変位 (部 材に軸力が発生しない変形) が生じる。一方, 有限変位 の範囲で考えると, (a) は剛体変位が可能であるが, (b) は軸力が発生し荷重とつり合うことによって剛体変位が 不可能である。このように（a）と（b）は異なる性質 を持つ構造形態であるが, 本研究ではともに微小変位の 範囲で力のつり合いがとれず, 剛体変位を生じる不安定 構造として扱う。本研究では安定節点間をつないでいる 部材を安定部材とし, 安定節点と安定部材から構成され る構造を安定構造と定義する。

2-2 安定判断の知識ベース

本研究では, 安定判断の知識として次の 3 つについて 知識整理を行った。

1) トラスの一般的な安定構造の知識

2）安定節点から新しい安定構造を探すための経験的 知識

3）複雑な構造を単純な構造に置に換えるための知識 2-2-1 トラスの一般的な安定構造の知識

全体のトラス構造からピン支持やローラ一支持をもと に探し出される安定した構造形態には，図一5に示すよ うな 3 つの構造が考えられる。これらの構造は，部材を 節点間のつながりとして表現すれば，

ルール 1 ：ある節点が 2 箇所のピン支持とつながってい る構造は安定構造である。ただし，2 箇所の ピン支持と節点との位置関係が直線となる場 合（幾何学的不安定）を除く。

ルール 2 : ピン支持とローラー支持がつながっている構 造は安定構造である。ただし，ピン支持よロー

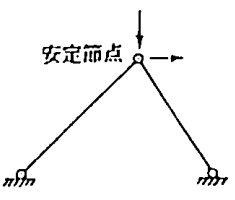

図一3 安定構造
不较赶管䈍

(a) 外部的不安定

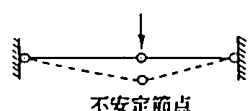

(b) 何学的不安定

図一4 不安定構造

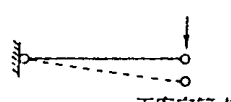

ラー支持をつないでいる部材とローラ一支持 の傾斜方向が直交している場合（幾何学的不 安定) を除く。

ルール $3: 3$ 箇所のローラー支持が 3 本の部材でつな がっている構造は安定構造である。ただし， 傾斜方向がすべて同じ場合（平行移動）また は，傾斜方向に直交する直線が 1 点で交わる 場合（回転移動）を除く。

\section{と知識整理できる。}

これらのルールの表現は, 条件部と実行部とから構成 されるプロダクションルールで次のように Prolog 言語 で記述している。

ルール名：一条件部, 実行部.

条件部は, 安定した構造形態を記号的に表現した部分で あり，この条件部を基に安定となるための節点と部材の 組み合わせが全体構造の中から探し出される。実行部に

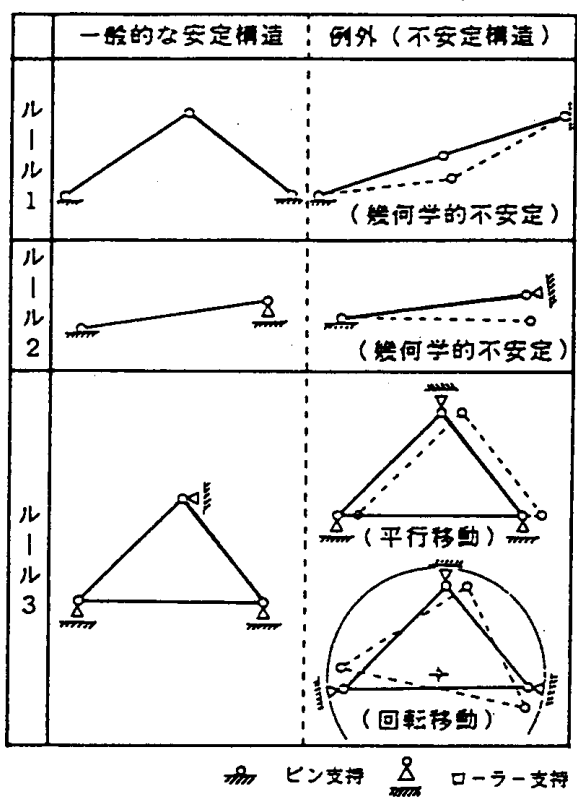

図一5 トラスの一般的な安定構造

find_stable_basic:-

node( _, _, NODEl, sup(pin))

$\operatorname{node}\left({ }_{-}, \ldots\right.$ NODE2, $\left.\sup (\operatorname{pin})\right)$,

NODE $1 /==$ NODE2,

check_truss (BL1, NODE1, NODE3), not(stable_node(NODF3, stable)), check_truss (BL2, NODE2, NODEJ), not (check_uns table_set(NODE1, NODE2, NODEJ)), node_position (NODE1, NODE2, NODE3), del_truss(BL1, NODE1, NODE3), del_truss(BL2, NODE2, NODE3), ass_stable_node(NODEJ, stable). change_state(BL1), change_state(BL2). NODF.3

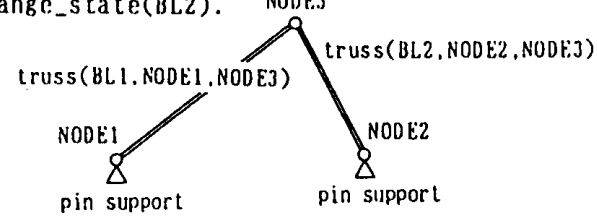

図一6 ルール1の安定構造を認識する知識表現 
find_stable_basic:-

node (X1, Y1, NODE1, sup(pin)),

check_truss (BL, NODE1, NODE2)

$\operatorname{node}(X 2, Y 2, \operatorname{NODE} 2, \sup (R A D)), R A D /==p i n$,

not (stable_node(NODE2, stable)),

check_right_angle $(X 1, Y 1, X 2, Y 2, R A D)$,

del_truss(BL, NODEL, NODE2).

ass_stable_node(NODE2, stable). change_state(BL)

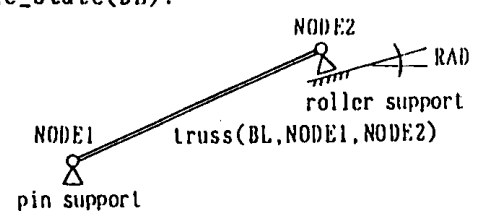

图一7 ルール 2 の安定構造を認識する知識表現

find_stable_basic:-

node (_, , NODE1, sup(RAD1)), RAD1/==pin,

not(stable_node(NODEi, stable)),

check_truss(BL1,NODE1,NODE2),

node (_, , NOBE2, sup(RAD2)), RAD2/==pin,

not(stable_node(NODE2, stable)),

check_truss (BL2, NODE2, NODE3),

node $(\ldots, \ldots, N O D E 3$, sup $(R A D 3)), R A D 3 /==p i n$.

not (stable_node(NODE3, stable)).

check_truss (BL3, NODEJ, NODE 1),

not (check_uns table_set(NODE1, NODE2, NODE3)),

rad_check(NODE1, NODE2, NODE3).

node_position (NODE1, NODE2, NODE3),

del_truss(BL1, NODE1,NODE2).

del_truss (BL.2,NODE2, NODE3),

del_truss(BL3, NODE3, NODE1),

ass_stable_node(NODE1,stablc),

ass_stable_node(NODE2, stable).

ass_stable_node(NODE3, stable),

change_state(BL1),

change_state(BL2),

change_state(BL3).

rolier support, $\forall$ RAi)

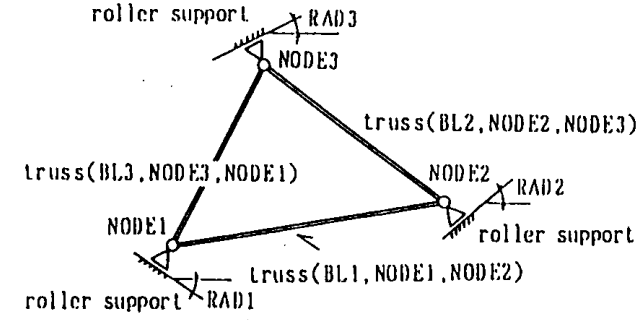

図一8 ルール 3 の安定構造を認識する知識表現

は，条件部で探し出された安定構造を新しい事実として データベース内に記憶するための処理が記述されてい る。具体的なルール 1 3 の表現を図一 $6,7,8$ に示す。

2-2-2 安定節点から新しい安定構造を探すための経験 的知識

部材によって安定節点とつながっている節点は, 部材 方向に拘束を受けることから，図一9に示すような構造 も安定である。したがって，すでに記憶されている安定 節点を基に新しい安定構造を探すための経験的知識は， ルール 4:ある節点が 2 箇所の安定節点とつながってい る構造は安定構造である。ただし，3つの節 点の位置関係が直線となる場合（幾何学的不 安定）を除く。

ルール 5：ローラー支持が安定節点とつながっている構

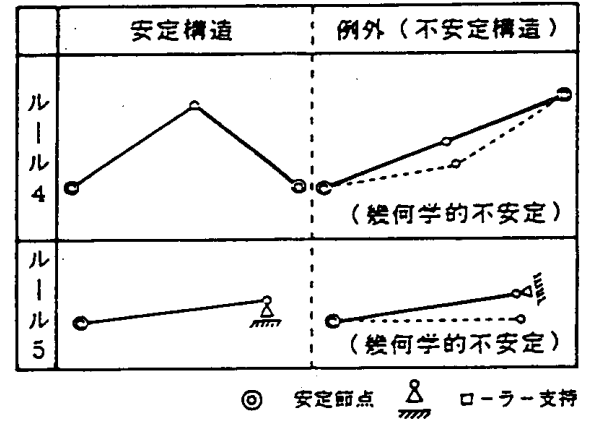

図一9 安定節点から見つけられる安定構造

find_s table_node:-

stable_node(NODE 1, stable),

check truss (BL1,NODEl, FIND_NODE).

not (stable_node(FIND_NODE, stable)),

check_truss (BL2,NODE2,FIND_NODE),

stable_node(NODE2, stable),

NODE $1 /==$ NODE2,

node_pos ition(NODEl, NODE2, FIND_NODE).

del_truss(BL1,NODE1,FIND_NODE).

del_truss(Bl,2,NODE2,FIND_NODE)

ass_stable_node(FIND_NODE,stable),

change_state(BL1),

change_state(BL2).

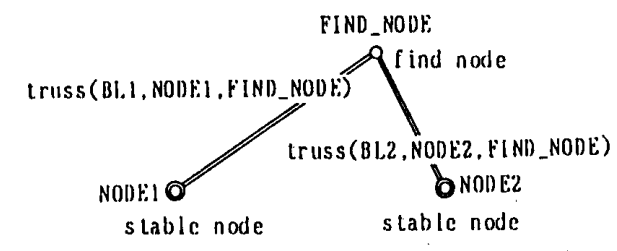

図一10 ルール 4 の女定構造を認識する知識表現

find_stable_node:-

node (XR, YR, ROLLER, sup (RAD)), RAD/==pin, not.(stable node(ROLLER, stable)). check_truss (BL, ROLLER, NODE), stable_node (NODE, stable).

node $(X \bar{N}, Y N, N O D E$, , $)$,

check_right_angle $(X R, Y R, X N, Y N, R A D)$,

del_truss (BL, ROLLER, NODE).

ass_stable_node(ROLLER, stable).

change_state(BL).

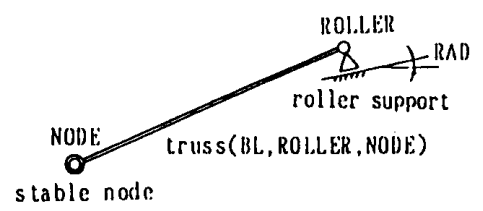

図一11 ルール 5 の安定構造を認識する知識表現

造は安定構造である。ただし, 安定節点とロー ラ一支持をつないでいる部材とローラ一支持 の傾斜方向が直交している場合（幾何学的不 安定) を除く。

である。ルール 4 の表現を図一10にルール5の表現を 図一11に示す。

2-2-3 複雑な構造を単純な構造に置き換えるための知 識

ルール 6：内部的に安定した部分構造の認識

図一12，13 に示すようなトラス構造は，前述の知識だ けで安定判断できるほど単純なものではない。このよう 


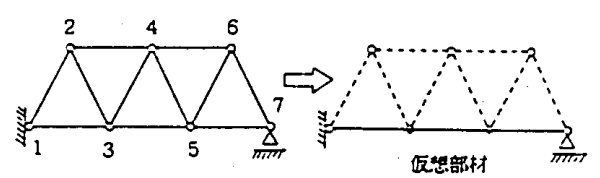

（a）内部的に安定な部分㜔造を（b）1本の仮想部材によって 持つ觧定トラス 单能化された槽造

図一12 典型的な静定トラスの例

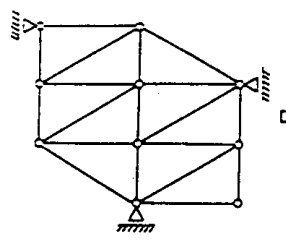

(a)単純化前のトラス啃造

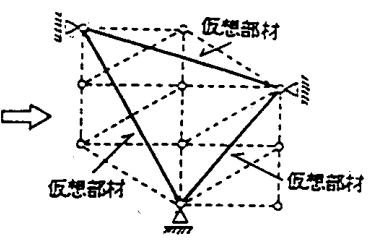

b ） 3 本の仮想部材によって 単純化された槽造
図一13 複数の仮想部材で単純化される構造例
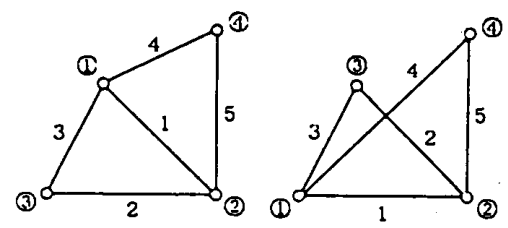

(a) 三角形トラスから挠成されるブロックの例

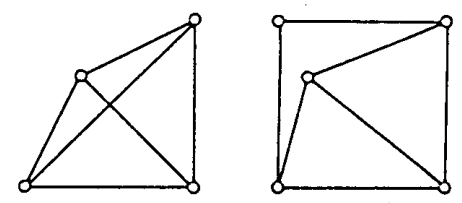

(b) 三角形トラスと2ヶ所以上つながる節点を 合めたフロックの例

図一14内部的に安定している部分構造（ブロック）

に複雑な構造の安定判断には, 内部的に安定した部分構 造の認識が必要である。つまり, 内部的に安定した部分 構造を認識し，この部分構造を 1 本あるいは数本の部材

(以下，仮想部材と呼ぶ）に置き換えることによって構 造自体が単純化される。この単純化によって, 複雑な構 造もルール 1〜5の安定した構造形態の知識だけで安定 判断が可能となり, また, 判断の対象とする構造の探索 空間を縮小することで安定判断の効率がよくなる。

内部的に安定した部分構造（ブロック）とは，2つ以 上の三角形トラスから構成される部分構造（図一14(a)） と三角形トラスと 2 䇢所以上つながる節点を含めた部分 構造（図一14(b)）である。また，ブロックの核となる 部分構造は, 図一14(a) のような 3 つの節点亡 3 本の部 材から構成される三角形トラスとさらに 1 つの節点をつ なぐための 2 本の部材を含めた計 4 節点 5 部材の部分構 造である。このブロックの核となる構造を見つける知識 表現を図一15 に示す。

図一16 は，ブロックの核となる構造とつながる節点 を探す知識表現である。認識されたブロックは，他のブ ロックと区別するために識別番号をつけ，このブロック に含まれる節点を図一2(d) の形式で記憶する。 find_stable_block:-

check _truss (BL1, NODE1, NODE2), check_truss (BL2, NODE2, NODE3), check_truss (BL3, NODE3, NODE1). not (check_unstable_set (NODE1, NODE2, NODE3)), check same block (BL1, BL2, BL, 3), check_truss (BL4, NODE1, NODE4), NODE4/ $==$ NODE3 check_truss (BL5, NODE2, NODE4). not (check_uns table_set (NODE1, NODE2, NODE4)), node_positi on (NODE1, NODE2, NODE3), node_position (NODE1, NODE2, NODE4). ass_block_number(NO), del_truss(BL1, NODE1, NODE2). del_truss(BL2,NODE2,NODE3), del_truss (BL3, NODEJ, NODE1), del_truss(BL4, NODE1, NODE4). del_truss (BL5, NODE2, NODE4), ass_stable_node(NODE1, block(NO)). ass_stable_node(NODE2, block(NO)). ass_stable_node(NODEJ,block(NO)), ass_stable_node(NODE4, block(NO)). change_block_number (BL1, NO), change block number (BL2,NO), change_block_number (BL3,NO), change_block_number (BL4,NO). change_block_number( $B L 5, N O)$, repeat,

check_block_node (FIND_NODE, NO) FIND_NODE=not_find, !

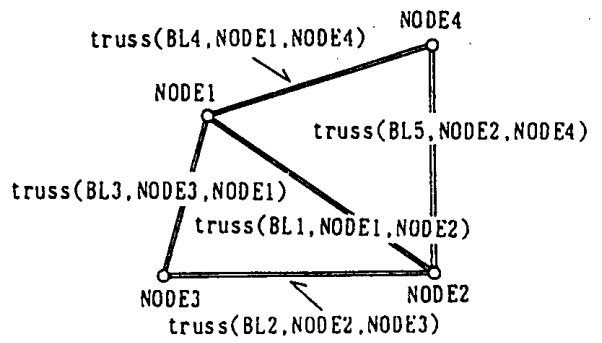

図一15 ルール 6-1 のブロックの核となる構造を認識する知識 表現

find_block_node(FIND_NODE, NO) :-

stable_node(NODE 1, block(NO)),

check_truss(BL1, NODE1, FIND_NODE).

not (stable_node(FIND_NODE, block(NO))), check_truss (BL2, NODE2, FIND_NODE), NODE1/==NODE2,

stable_node(NODE2, block(NO)).

node_position(NODE1, NODE2, FIND_NODE)

del_truss(BL1,NODE1, FIND_NODE).

del_truss(BL2, NODE2,FIND_NODE),

block_paint (NODE1,NODE2, FIND_NODE),

ass_stable_node(FIND_NODE, block(NO)), change_block_number (BL1, NO).

change_block_number(BL2,NO),!.

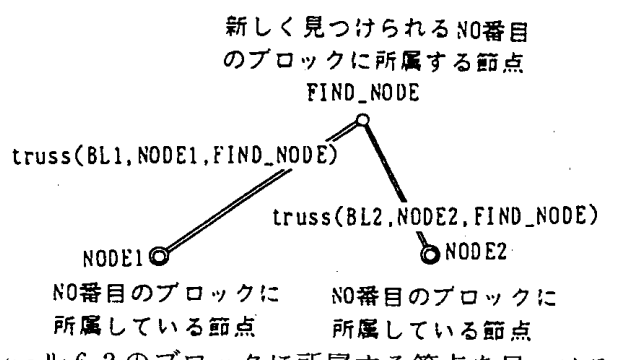

図一16 ルール 6-2 のブロックに所属する節点を見つける知識 表現

次に，ブロックの仮想部材への置き換えについて述べ る。

仮想部材を考えるときにつながる対象となる節点は, 
uake_truss:-

needful_node(SUP1, sup, NO),

needful_node(SUP2, sup,NO),

SUP 1/==SUP2,

not (check_truss(NO, SUP1, SUP2)),

assertz(truss(NO, SUP1, SUP2)),

ass_continue, fail.

make_truss :-

needful node(SUP, sup, NO),

needful_node(NODE, stable, NO).

SUP $/==$ NODE ,

$\operatorname{not}($ check_truss(NO,SUP,NODE))

assertz (truss (NO, SUP, NODE)),

ass_continue, fail.

make_truss:-

needful_node(SUP, sup, NO),

needful_node(NODE, joint, NO).

SUP/ $==$ NODE

not (check_truss(NO, SUP,NOOE)),

assertz(truss (NO, SUP, NODE)),

ass_continue, fail.

make_truss:-

needful_node(NODE1,joint, NO)

needful_node(NODE2, jo int, NO),

NODE $1 /==$ NODE 2 .

not (check_truss(NO,NODE1, NODE2)),

assertz(truss(NO,NODE1,NODE2)).

ass_continue, fail.

make_truss:-

needful_node(NOOEl, joint,NO),

needful_node(NODE2, stable, NO),

NODE $1 /==$ NODE2 .

not (check_truss(NO, NODE1, NODE2)),

assertz(truss(NO, NODE1, NODE2)).

ass_continue, fail.

aake_truss: - !

図一17 ルール6-3のブロックを仮想部材へ置き換える知識表 現

(1)ブロック内の安定節点，(2)ローラー支持またはピン支 持されている節点, (3)他のブロックまたはトラス部材と つながっている節点である。これらの節点を見つけ仮想 部材に置き換える知識表現を図一17 に示す。

例えば，図一12 は，まずブロックの核として節点 1 , 2，3，4 とそれらをつなぐ部材から構成される部分が見 つけられる。さらに，節点 $5,6,7$ の順でこのブロック に所属する節点が見つけられていく。このブロック内に はピン支持とローラー支持されている節点が存在するた めこれらの節点をつなぐ 1 本の仮想部材に置き換えられ る。複数の仮想部材に置き換えられる例を図一 13 に示 す。

ルール $7:$ ローラー支持と等価な節点の認識

図一18(a) に示すようなある節点が安定節点とつな がっている構造において,安定でない方の節点を考える。 この節点の部材方向の変位 $U$ は, 変位によって部材軸 力が発生するため拘束を受けている。部材方向に対して 直交方向の変位 $V$ は, 部材軸力による抵抗がなく自由 に移動できる。したがって，このような節点は，部材と 直交方向に変位を許すようなローラ一支持に置き換える ことができる。このような知識を図一19に示す。

例えば, 図一20(a) のようなトラス構造は,ルール 2 によってピン支持とローラー支持とその両者をつなぐ部

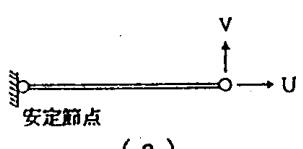

(a)

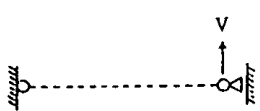

(b) ローラー支持と

等佰な第点
図一18 ローラー支持と等価な節点

make_support:-

stable_node(NODEl, stable),

check_truss(_, NODE1,NODE2).

node $(X 1, Y 1, N O D E 1, \ldots)$.

node (X2,Y2, NODE2, free).

$X$ is $X 2-X 1, Y$ is $Y 2-Y 1$,

$\operatorname{rol} \operatorname{rad}(X, Y, R A D)$

retract(node $(X 2, Y 2$, NODE2, f ree $))$.

assert (node $(X 2, Y 2, \operatorname{NODE} 2$, sup (RAD)))), ass_continue, fail.

make_support:-!

図一19 ルール 7 のローラー支持と等価な節点を認識する知識 表現

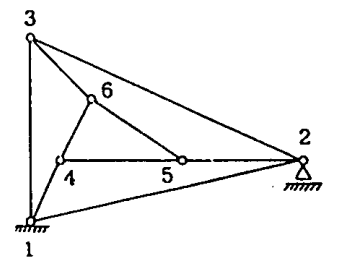

(a)

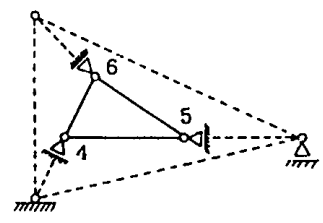

(b)
図一20 ローラー支持に置換できる節点を含むトラス構造

材からなる部分構造が安定であることがわかり，ルール 3 によって，節点 3 も安定節点であることが導かれる。 ここで，節点 $4,5,6$ をローラ一支持と等価な節点であ ることに注目すると，節点 $4,5,6$ からなる部分構造の 安定判断を図一20(b) の構造について行うことができ る。

2-3 安定判断の推論アルゴリズム

本研究の知識ベースに基づく安定判断の推論アルゴリ ズムは，大きく4つのステップに分かれており終了条件 を満たすまで繰り返される。

(準備) ピン支持されている節点は安定節点としてあ らかじめデータベースに記憶しておく。

(ステップ1) トラスの一般的な安定構造の知識を利用し て，ピン支持やローラー支持をもとに安定 した構造形態を探し，その構造に含まれる 節点を安定節点としてデータベースに記憶 する。

(ステップ2)すでにデータベースに記憶されている安定 節点をもとに，新しい安定構造を探し，そ の構造に含まれる節点を安定節点として データベースに記憶する。

(ステップ3) 構造中で，まだ安定と判断されていない部 分から内部的に安定した部分構造（ブロッ ク）を探す。

(ステップ4) ステップ 3 で見つけ出したブロックに関す 

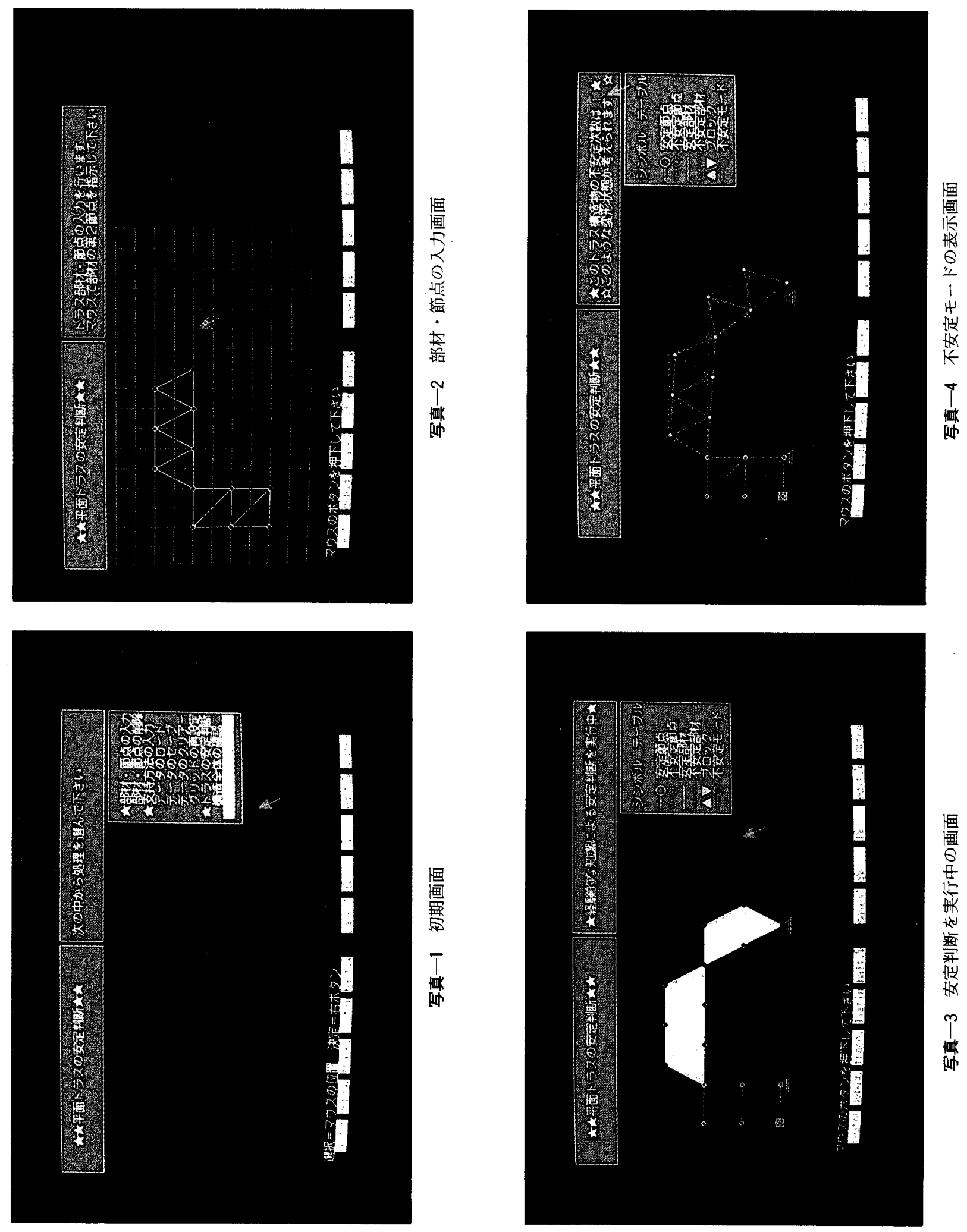

る情報を基にトラスを単純な構造に置き換 える。ここで, 構造の単純化が可能であれ ば，ステップ1に戻り再び単純化された構 造について安定判断を行う。全節点につい て安定と判断されたときや，ステップ 3 で ブロックを見つけ出せなかったとき，この 構造は単純化が不可能となり, 推論を終了

する。

（判断） 最終的な推論の結果, 全節点が安定節点ならば, 構造全体を安定構造と判断し，また，安定節点 とならない節点が残っているときは, 両端が安 定節点とつながる部材とし，構造全体を安定構 造部分と不安定構造部分とに分けた状態を判断 結果とする。 


\section{3. 平面トラスの安定判断システム}

平面卜ラスは，構造物の中で最も単純であり，かつ基 本的なものである。平面卜ラスの応力解を求める手順や 計算方法は，授業ならびに教科書 ${ }^{3)} て ゙$ 比較的詳しく説明 されている。また，トラス構造の安定不安定を判断する 能力はきわめて重要であると指摘されている。この判断 能力は，様々なトラス構造を解くことによって養われ，

経験的知識として蓄積されると考えられる。

そこで，2 章で述べた安定性に関する知識に基づいて その判断過程を表示することにより，視覚的に平面トラ スの安定判断の感覚を身につけることのできることを配 慮した。このような視覚的機能を十分に完成させること

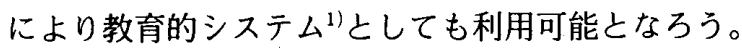

\section{3-1 システムの概要}

本システムは, 次の 4 つの特徵を有している。

1）安定判断の対象となるトラス構造のデー夕を画面 と対話しながら作成する（写真一2）。

2) 安定判断の過程を表示する (写真一3)。

3）安定判断の結果をグラフィック表示する（写真一 4)。

4）不安定モードを計算し表示する（写真一4）。

経験的知識による安定判断は，節点間のつながりに関 するネットワーク情報に基づいているため, 変形状態を 考慮しないと判断できない構造に対しては正確な判断が できない。そのため，不安定と判断された部分構造の剛 性マトリックスを Fortran 言語で数値的に解析 ${ }^{4)-9)}$ し, その不安定モードを求めることは, 経験的知識による判 断の信頼性を数理理論的立場から確認することでありき わめて重要である。また，本システムの利用者に対して， ビうして不安定なのかという理由を不安定モードを表示 することによって理解させることができ，不安定構造を 安定構造にするための有用な手がかりを提示することと なる。

本システムの基本機能を図一 21 に示し，本システム の初期画面を写真一1に示す。不安定構造については, 表示された不安定モードから部材の再配置・追加および 支持の変更・追加を行い，再び安定判断をすることがで きる。この繰り返し機能によって利用者は, 視覚的に平 面卜ラスの安定判断の感覚を身につけることができると 思われる。

\section{3-2 システムの実行例}

安定判断の対象として図一 22 に示すトラス構造につ いて実行する。このトラス構造の入力状態を写真一 2 に 示す。写真一 3 は, 安定判断の過程である。緑色の部材 で構成される部分構造は安定であり, 黄色の部分をブ ロックと認識している。

安定判断の結果,このトラスは部分的に不安定と判断 され，その部分の不安定モードを赤色の実線で表示し，

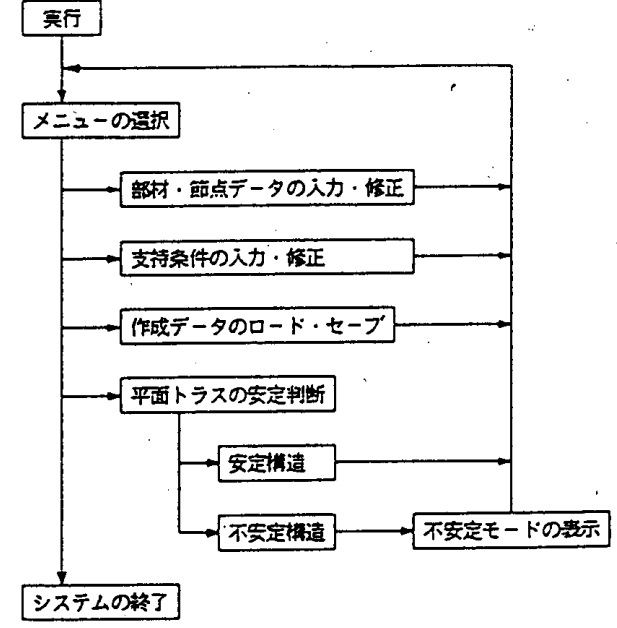

図-21 システムの基本機能

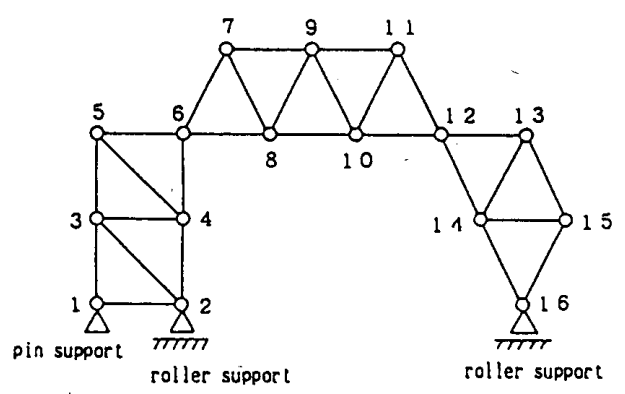

图一22実行例に用いるトラス構造

不安定次数が 1 次であることが表示されている（写真一 $4)$ 。

この不安定モードより節点の移動を 1 箇所拘束する か，または適切なところに 1 本部材を加えれば良いこと がわかる。ここで, 図一 23 のように節点 16 のローラー 支持をピン支持に変更して再び安定判断を行う。

図一23 の安定判断の過程を具体的に説明すると次の ようである。

\section{【準 備】}

まず，ピン支持されている節点 1 と節点 16 を安定し た節点としてデータベースに記憶する（図一24(b)）。

【1 回目のステップ1】

一般的な安定構造を全体から探す。このときルール 2 を適用して，節点 1 のピン支持と節点 2 のローラー支持 をつなぐ構造を安定構造として, 節点 2 を新しく見つ かった安定節点としてデータベースに記憶する（図一24 (c))。

【1 回目のステップ 2】

安定している節点から新しい安定節点を探す。節点 1 と節点 2 が安定節点となっているためルール 4 を適用し て, 節点 3 を新しい安定節点としてデータベースに記憶 する。さらに今度は, 節点 2 と節点 3 が安定節点となっ たため節点 4 が安定節点であることが導かれる。同様に, 節点 5 , 節点 6 の順に安定節点であることが導かれ, デー タベースに記憶される（図一 $24(\mathrm{~d}))$ 。 


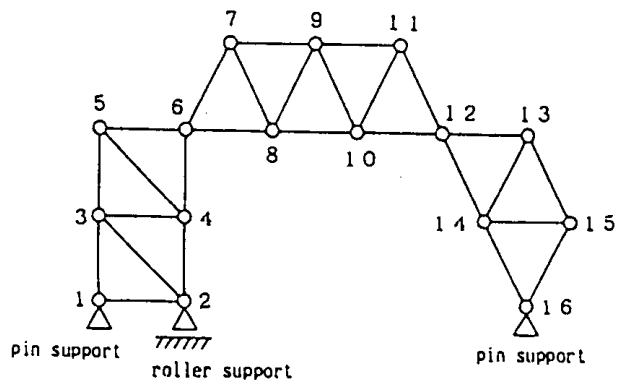

図一23図一22 のトラス構造を安定構造となるように修正した 構造

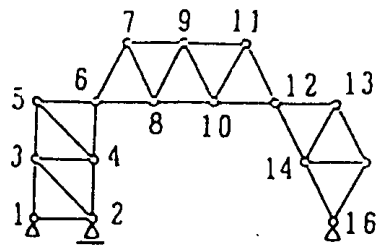

(a) 判断するトラス成造

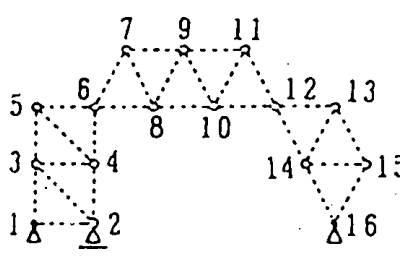

(b) 傮 $7+\frac{9}{10}+\cdots$

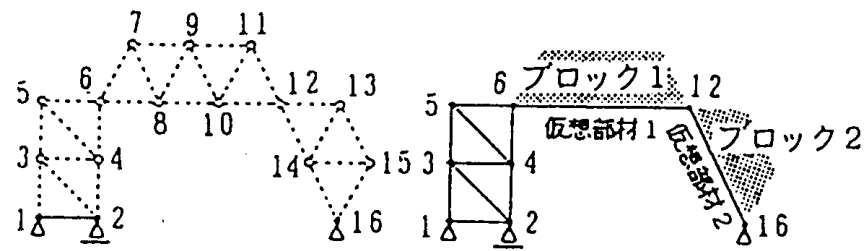

(c) 1 回目のステッフ 1 の状照 （g） 2 回目のステッフ 2 の状照

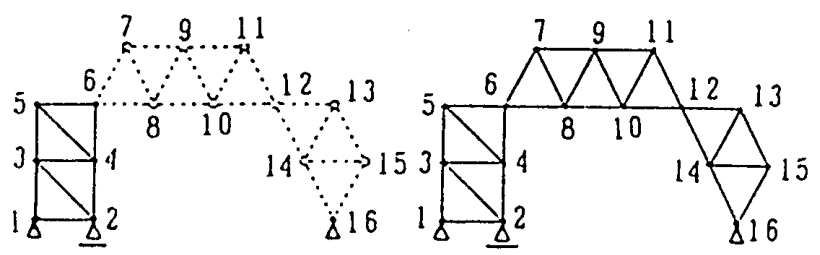

(d) 1 回目のステップ 2 の状㤎

(h) 䅂判断

図一24 図一 23 のトラス構造の安定判断過程

\section{【1 回目のステップ 3】}

内部的に安定した構造（ブロック）を探す。節点 6 , $7,8,9,10,11,12$ とその節点をつなぐ部材からなる部 分構造を 1 番目のブロックとして認識する。さらに，節 点 $12,13,14,15,16$ とそれらをつなぐ部材からなる部 分構造を 2 番目のブロックとして認識する(図一 $24(\mathrm{e}))$ 。 【1 回目のステップ4】

構造の単純化を行う。1 番目のブロックを節点 6 と節 点 12 をつなぐ仮想部材 1 に置き換える，同様に，2 番 目のブロックについても節点 12 と節点 16 をつなぐ仮想 部材 2 に置き換える（図一 $24(\mathrm{f}))$ 。

【2 回目のステップ1】
【2 回目のステップ 2】

ルール 4 を適用して, 節点 6 と節点 16 が安定節点で あることから，節点 12 とそれをつなぐ仮想部材 1 , 仮 想部材 2 からなる構造を安定構造とする。このとき, 仮 想部材 1 と仮想部材 2 が安定部材となることから，1 番 目のブロックと 2 番目のブロックに含まれているすべて の節点を安定節点として記憶する（図一24(g))。

【2 回目のステップ3】

【2 回目のステップ4】

全節点が安定節点となったため，構造の単純化をする 必要がなく推論を終了する。

\section{【判 断】}

全節点が安定節点であるため, 全体的に安定構造と判 断できる(図一24(h))。

\section{4. まとめ}

本研究は，平面トラスの安定判断のために必要となる 経験的知識や判断方法を知識工学的手法によって整理 し,これらの経験的知識を利用した平面トラスの安定判 断システムを知識ベースと数理解析理論に基づいて試作 した。種々の平面トラスのモデルについて知識ベースの みに基づいて判断を行った結果, 従来の安定性の判断法 による結果と現在のところ一致しており，本システムは ほぼ工学的に満足のいくものである。しかしながら，本 知識ベースは平面トラスのみの安定判断を対象としたも のであり,安定性の全問題領域を対象としていないため, きわめて制限の強い知識ベースとなっている。つまり, 従来の安定性に関する数理解析理論に比較すれば, 本研 究に示した数少ない知識ベースだけによる判断システム の能力は，実用性が十分にあるとは言えない。この不十 分さを補完するため，知識処理言語と数値解析用言語を 併用するシステムの可能性を確かめる意味からも，従来 の数理解析理論をシステムの中に含めることにより実用 性を高めようとした。今後，このような方向の研究を蓄 積すれば，より実用性，信頼性の高いシステムに完成し うる可能性がありえよう。

\section{文 献}

1) DAVID J. GUNARATNAM : A KNOWLEDGE-BAS. ED EXPERT SYSTEM FOR TUTORING IN STRUCTURAL ENGINEERING, Computers and Structures, Vol. 30, No.3, pp.767-773, 1988.

2) 加藤史郎, 杉山 武, 山口源一郎 : Prolog 言語による平 面トラスの安定判断システム, 日本建築学会東海支部研 究報告集, 第 27 号, pp. 185-188, 平成 1 年 2 月.

3）横尾義貫, 小西一郎ほか：構造力学第一巻, 丸善株式会社, 昭和 41 年.

4）和田 章, 久保田英之：不安定構造物の解法に関する研 究, 日本建築学会構造系論文報告集, 第 387 号, pp. 3544 , 昭和 63 年 5 月. 
5) 田中 尚, 半谷裕彦: 不安定トラスの剛体変位と安定化 条件，日本建築学会構造系論文報告集，第 356 号， pp. $35-42$, 昭和 60 年.

6) 半谷裕彦, 川口健一: 不安定リンク構造の形状決定解析, 日本建築学会構造系論文報告集, 第 381 号, pp. 56-60, 昭和 62 年.

7) 半谷裕彦: 一般逆行列とその応用, 有限要素法の最近の トピックス, 日本鋼構造協会, pp. 103-118, 昭和 52 年 2 月.

8）柳井晴夫，竹内 啓：射影行列 - 一般逆行列 - 特異值分 解, UP 応用数学選書 10 , 東京大学出版, 昭和 58 年 7 月.

9）二宮市三：特異值分解による一般化逆行列プログラム (GINVS)，ライブラリー・プログラム利用の手引, pp. 48-50, 名古屋大学大型計算機センター, 昭和 57 年 6 月.

10）中村秀治, 寺野隆雄：土木構造物のエキスパートシステ 么, オーム社, 昭和 62 年.

11）加藤史郎，杉山 武，山口源一郎：構造物の安定性に関 する知識整理と安定判断システム, 日本建築学会大会梗 概集（構造 I)，pp. 989-990，平成 1 年.

12) A. Bar, E. A. Feigenbaum 編, 田中幸吉, 淵 一博監 訳：人工知能ハンドブック第 I 巻, 共立出版, 昭和 58 年.

13) F. Hayes-Roth, D. A. Waterman, D. B. Lenat 編, AIUEO 訳：エキスパート・システム, 産業図書, 昭和 61 年.

14）上野晴樹, 石塚 満: 知識の表現と利用, オーム社, 昭 和 62 年.

15）萩野達也, 桜川貴司：Prolog-KABA Reference Manual, アステック，昭和 62 年.

16）繁 周作, 稲葉 輝: Prolog-KABA 拡張ツール WING Reference Manual, 岩崎技研, 昭和 62 年.

17）小野 定：コンクリートのひび割れ診断システム, 土木 における ES と CAD, pp. 25-34, 平成 1 年.

18）小澤由紀夫ほか：最適土地利用企画エキスパート・シス テムの研究と開発, 日本建築学会計画系論文報告集, 第 400 号, pp. 51-59, 平成 1 年.

\section{付 録}

本システムで開発した各種の知識ベースの内重要なものにつ いて説明する。

（注）本システムは，PC-9801（マウス使用）上で安定判断 部をProlog-KABA ${ }^{12)}$ おひび Prolog-KABA 拡張ツール $W^{2} \mathrm{ING}^{13)}$ で, 不安定モード解析部を Fortran 言語で作成した。 なお，本システムのリストは，無償で配布する。

check-truss（ブロック番号，節点 1 ，節点 2)

この述語は，「節点 1 と節点 2 が 1 本の部材によってつな がっている」または仮想部材に対して『節点 1 と節点 2 が内 部的に安定した構造によってつながっている」ことを表して いる。実際の処理は, 引数の節点 1 と節点 2 の值がすでに決っ ている場合, 節点 1 と節点 2 がつながっているという情報が データベースに存在するかどうかを検証する。また, 節点 1 だけ值が決定していて, 節点 2 が未決定である場合, 節点 1
とつながっている節点をデータベース中の情報から検索し， 節点 2 にその節点番号を返す。逆に，節点 2 が決定值で節点 1 が変数の場合も同様である。ブロック番号は, 内部的に安 定した部分構造を置き換えた仮想部材と実際に存在する部材 とを識別するための番号である。

node $(X$ 座標, $Y$ 座標, 節点番号, $\sup ($ pin $))$

node $(X$ 座標, $Y$ 座標, 節点番号, sup (傾斜角) )

node $(X$ 座標, $Y$ 座標, 節点番号, free)

この述語は, 節点の座標, 支持状態を表している。実際の 処理は，節点が支持されているかを確認することと支持され ている節点を検索することである。

stable-node (節点番号, stable)

この述語は，節点が安定していることを表している。実際 の処理は，節点が安定しているかを確認することと安定節点 を検索することである。

stable-node (節点番号, block (ブロック番号))

この述語は，節点がブロックに所属していることを表して いる。実際の処理は, 節点がブロックに所属しているかを確 認することとブロックに所属している節点を検索することで ある。

node-position (節点 1, 節点 2 , 節点 3 )

この述語は，節点 1 ，節点 2 ，節点 3 の位置関係が直線でな いことを確認する。これは, 安定構造の例外を排除するため のものである。

check-right-angle $(X 1, Y 1, X 2, Y 2$, ローラー支持の傾斜 角)

この述語は，ローラー支持とつながっている部材について， 部材方向とローラー支持の傾斜方向が直交していないことを 確認する。

not (check-unstable-set (節点 1 , 節点 2 , 節点 3))

この述語は, 節点 1 , 節点 2 , 節点 3 から構成される構造が, すでに不安定構造として記憶されていないかを確認する。 ass-stable-node (安定節点, stable)

この述語は，新しく見つかった安定節点をデータベースに 記憶する。

del-truss (ブロック番号, 節点 1, 節点 2)

この述語は，見つけられた安定構造やブロックに含まれる 節点 1 と節点 2 をつなぐ部材の情報をデータベースから削除 する。

change-state (ブロック番号)

この述語は, 安定構造と判断されたブロックに含まれる節 点をすべて安定節点としてデータベースに記憶する。 needful-node (節点番号, stable, ブロック番号)

needful-node (節点番号, sup, ブロック番号) needful-node (節点番号, joint, ブロック番号)

この述語は, 仮想部材を考えるときに対象となる節点を見 つけ出す。ここで, stable はブロック内の安定節点を見つけ 出し, sup はピン支持またはローラー支持されている節点を 見つけ出す。また, joint はほかのブロックとつながっている 節点またはトラス部材とつながっている節点を見つけ出す。

(1989 年 10 月 27 日原稿受理, 1990 年 4 月 7 日採用決定) 